\title{
ГЕРМЕНЕВТИКА АКАДЕМІЧНОЇ ДОБРОЧЕСНОСТІ В КОНТЕКСТІ ДУХОВНОЇ ПАРАДИГМИ ПСИХОЛОГІЇ
}

\author{
Ольга Климишин \\ доктор психологічних наук, доцент, \\ професор кафедри психології розвитку \\ Прикарпатський національний університет імені Василя Стефаника \\ 76005, Україна, м. Івано-Франківськ, вул. Шевченка, 57 \\ klymyshyn@meta.ua, https://orcid.org/0000-0002-3943-4397
}

\begin{abstract}
Анотація
В умовах проведення освітніх реформ 3 орієнтацією на європейські стандарти виникає необхідність осмислення фундаментальних цінностей, на яких повинен базуватися i реалізовуватися освітній процес. У статті висвітлено результати дослідження академічної доброчесності як конгломерату духовних цінностей, що презентують особистісну позицію представника академічної спільноти в освітньому просторі. Мета дослідження: розкрити зміст феномена академічної доброчесності в контексті духовної парадигми психології. Завдання дослідження: 1) означити методологічні положення духовної парадигми психології; 2) розкрити зміст ціннісних спектрів академічної доброчесності в контексті духовної парадигми психології. Для розкриття змісту феномена академічної доброчесності в контексті духовної парадигми психології були використані теоретичні методи - аналіз, синтез, порівняння, узагальнення і систематизація теоретичних підходів і поглядів до проблеми академічної доброчесності, психологічна герменевтика. Висхідним положенням аналізу академічної доброчесності в контексті духовної парадигми психології є розгляд особистості представника академічної спільноти як ноологічної сутності, що характеризується потенційною універсальністю, творчо-вольовою спрямованістю, іманентною здатністю до вибору добра та заперечення зла, онтологічною налаштованістю до самопізнання та самовизначення заради утвердження трансцендентних духовних цінностей. Духовні цінності, які становлять суть академічної доброчесності, актуалізуються в свідомості студента, викладача (відповідно до конкретної ситуації вибору в умовах освітнього процесу), проходять щоразу «внутрішнє переосмислення» крізь призму деонтичного вибору та прийняття відповідальності за його здійснення, за наслідки, після чого відбувається реалізація цих цінностей у вчинковий спосіб.
\end{abstract}

Ключові слова: особистість, академічна доброчесність, духовність, духовні цінності, чесність, довіра, справедливість, повага, відповідальність, мужність.

\section{Вступ}

Одним із викликів сучасності $€$ реформування освітнього простору. Виникає необхідність переосмислення засадничих положень організації навчально-виховного процесу в освітніх закладах, орієнтованих на формування не лише знань, вмінь, навичок, а, передусім, розвиток особистісного потенціалу студента загалом. Закладам вищої освіти відводиться особлива роль у формуванні зрілої, цілісної, гармонійної особистості, яка вже завтра стане успішним професіоналом, справжнім сім'янином, національно свідомим 
громадянином, але, передусім, - людиною з усвідомленим і розвинутим почуттям власної гідності. Гідність є категорією, яка презентує аксіологічну природу людини, векторно спрямовану на всі сфери іiі життєздійснення.

Як влучно відзначено в Бухарестській Декларації етичних цінностей і принципів вищої освіти в Європейському регіоні, університети не можна розглядати як інституції, вільні від цінностей. Ті цінності та етичні стандарти, яким вони слідують, будуть не лише визначальним чином впливати на науковий, культурний i політичний розвиток їх академічного персоналу, студентів і співробітників, а й допоможуть у формуванні морального обличчя суспільства загалом. Як такі, університети повинні прийняти на себе пряму відповідальність і докласти всіх зусиль для досягнення етичних стандартів найвищого гатунку. Недостатньо слідувати високим моральним стандартам на рівні риторики. Вкрай важливо, щоб таких стандартів дотримувалися та втілювали їх в життя на кожному напрямі роботи закладів вищої освіти - не лише через викладання та програми досліджень, а й 3 точки зору керівництва та управління закладами і залучення зовнішніх стейкхолдерів (Фініков, 2016).

У цьому контексті виникає питання забезпечення в закладах вищої освіти умов дотримання і розвитку академічної доброчесності. Практично у кожному з них є чітко прописані Кодекси академічної доброчесності (з орієнтацією на світові стандарти), які регламентують навчальну та педагогічну діяльність як студентів, так і викладачів. Однак, чи знаходить ця регламентація завжди практичне втілення - залишається відкритим i проблемним питанням.

Технічний прогрес, як засвідчує практика, має неоднозначний вплив на якість освіти. 3 одного боку, маємо технічні можливості відслідкувати, перевірити тексти наукових робіт на їх оригінальність та новизну завдяки існуючим програмам антиплагіат, а, з іншого боку, $є$ можливість недоброчесного використання інтернет-ресурсів споживачами інформації. Здійснюючи пошуки інформації, студент, науковець не потребує тепер безпосереднього візиту в бібліотеку, опрацювання матеріалів бібліотечних архівів чи, навіть, передплати журналів. Він має можливість скористатись електронним форматом презентації книг, журналів, окремих статей і т.ін. в інтернет-мережах. Зауважимо, що й тут не обходиться без порушень - фінансових спекуляцій на працях авторів книг (продажі електронних варіантів праць без погодженості з автором), а також знеособлення окремих наукових доробок. За всім цим стоїть конкретна людина чи люди з відповідним рівнем розвитку їх ціннісно-смислової свідомості.

Вперше термін «академічна доброчесність» у його сучасній інтерпретації було використано в 1999 році в документі Міжнародного центру академічної доброчесності. В дослідженнях вітчизняних i зарубіжних учених (А. Артюхов, Т. Бретаг, Б. Буяк, I. Дегторьова, Т. Добко, М. Дойчик, Т. Лічман, А. Мельниченко, О. Меньшов, І. Олексів, В. Турчиновський, Т. Фініков, Т. Фішман, В. Хмарський та ін.) знаходимо широкий діапазон розкриття суті академічної доброчесності - в юридичній (правовій), освітній, соціальнокультурній площинах. Останнє десятиріччя українські науковці-освітяни активно вивчають зарубіжний досвід та долучаються до міжнародних проектів пропагування академічної доброчесності. Зокрема в межах діяльності Польсько-української фундації Інституту міжнародної академічної та наукової співпраці реалізуються проекти просвіти науковців, педагогів щодо питань академічної доброчесності. 
Як зауважив Т. Фініков, досягненню єдності академічної культури, високого рівня професійної етики, слідуванню моральним цінностям та стандартам слугує розвинена інфраструктура міжнародних та національних організацій, серед яких чільне місце займає вже згаданий вище Міжнародний центр академічної доброчесності (The International Center for Academic Integrity). Він розпочав свою діяльність в США ще в 1992 році як національна організація, а вже в 2010 році офіційно був перейменований у Міжнародний центр академічної чесності, що стало свідоцтвом міжнародного впливу та розширення членства в цій структурі. До 2014 року число членів цього об'єднання збільшилося до майже 250 установ і близько 1500 представників, розташованих у 21 країні на всіх континентах. Основним інструментарієм, який використовує центр, $є$ проведення щорічних міжнародних конференцій, організація дослідницьких проектів, розробка керівництв та рекомендацій для аналізу, оцінювання i побудови ефективних стратегій запровадження академічної доброчесності в освітню практику (Фініков, 2016).

Водночас питання сутнісно-функціональних особливостей академічної доброчесності, розробки психолого-педагогічних технологій формування академічної доброчесності в умовах освітніх закладів і надалі залишається відкритим.

Мета дослідження: розкрити зміст феномена академічної доброчесності в контексті духовної парадигми психології. Завдання дослідження: 1) означити методологічні положення духовної парадигми психології; 2) розкрити зміст ціннісних спектрів академічної доброчесності в контексті духовної парадигми психології.

\section{Методи дослідження}

Для розкриття змісту феномена академічної доброчесності в контексті духовної парадигми психології були використані теоретичні методи - аналіз, синтез, порівняння, узагальнення і систематизація теоретичних підходів та поглядів до проблеми академічної доброчесності, психологічна герменевтика.

\section{Результати та дискусії}

3 психологічної точки зору феномен академічної доброчесності має аксіологічну природу, адже його зміст утворюють такі фундаментальні цінності, як: чесність, довіра, справедливість, повага, відповідальність, мужність. Означені цінності здебільшого зіставляють із проявом моральності особистості. Однак, з нашої точки зору, їх сутніснофункціональна природа обумовлена духовною природою людини загалом. Як влучно зауважив М. Савчин, «гола», не оперта на духовність моральність не розвиває природні сили, а властивий їй волюнтаризм підпорядковує людину етичним імперативам. Проте, відомо, що крихкою та малоефективною є будь-яка автономна та іманентна етична система, що не містить ніякої животворної сили - духу (Савчин, 2019).

Відправними методологічними положеннями психологічного аналізу академічної доброчесності в площині духовної парадигми досліджень $\epsilon$, передусім, розуміння того, що:

1. Людина є холономно структурованою реальністю, яку творять такі рівні (холони), як тіло, душа, дух. Вони становлять єдину комплементарну цілісність, що визначає трансцендентальну універсальність та доцільність існування людини як одухотвореної істоти. Тіло репрезентує виключно людську природу, душа ж - божественну. Вона $є$ «вмістилищем» духовних можливостей. Відтак, психічні процеси, стани, властивості - це своєрідні механізми доцільного функціонування душі, які актуалізуються за умови 
підпорядкування душі духові. Дух виступає акумулятором і транслятором трансцендентного сенсу для душі. Духовні та психологічні вияви людини повинні розглядатися окремо, адже вони є сферами суттєво відмінними і духовне не зводиться до психічного (Савчин, 2011).

2. Духовне $\epsilon$ трансцендентним за походженням та іманентним за існуванням. В особистості є не лише глибини, але й вершини (Савчин, 2011). Особистість постає як ноологічна сутність, що характеризується потенційною універсальністю, творчо-вольовою спрямованістю, іманентною здатністю до вибору добра та заперечення зла, онтологічною налаштованістю до самопізнання та самовизначення заради утвердження трансцендентних духовних цінностей (Климишин, 2013).

3. Духовність як іманентне, внутрішнє утворення особистості, $є$ тією глибинною інстанцією, завдяки якій вона (особистість) стає самодостатнім суб'єктом життєдіяльності, спрямованим на творення добра для себе, для рідних, інших людей, здатним виражати любов до іншого, творчо концептуально переосмислювати і трасформувати обставини свого життя й власні потенційні можливості та боротьбу зі злом (Савчин, 2011).

4. Як форма презентування екзистенційно-творчого начала, Сутнісне Я зумовлює особистісну активність у двох площинах життєздійснення людини як духовної істоти: в горизонтальній, як середовищі діяльнісної самореалізації (морально-комунікативна, художньо-естетична, пізнавально-перетворювальна діяльність) та у вертикальній, яка репрезентує духовне зростання людини в онтогенезі шляхом іiі служіння трансцендентним цінностям.

5. Духовність трактується як складна динамічна система смислових утворень особистості, репрезентована етичним, естетичним, інтелектуальним та екзистенційним змістами процесів відображення та конструювання дійсності. Внутрішніми детермінантами їх утворення $\epsilon$ категорії добра і зла, прекрасного та потворного, істинного і помилкового, блага як сенсу, які апріорно представлені в психіці людини й актуалізовуються в процесі іiі соціалізації. Відповідно чесність, милосердя, співчуття, жертовність, довершеність, гармонія, вершинні переживання, правдивість, справедливість, мудрість, віра, надія, любов, мужність виступають духовними цінностями - диспозиціями особистості, яка перебуває на шляху духовного сходження до Святинь Духа (Климишин, 2013).

3 появою на світ людина володіє певною системою духовних інтенцій «Сутнісного Я», яке виступає формою представлення духа. Ці інтенції, як першосенси, становлять семантичний Всесвіт (Налімов \& Дрогалина, 1984) і спрямовують формування ціннісносмислової сфери особистості. Будучи усвідомленими й узгодженими 3 суспільними цінностями, вони перетворюються в особистісні смисли. Останні є динамічними системами об'єктивного відображення дійсності та емоційно-вибіркового ставлення до неї і являють собою своєрідний сплав афекту та інтелекту (Виготський, 2000), що робить людину суб’єктом життєздійснення, власне носієм духовної іпостасі (Климишин, 2013).

Академічна доброчесність є конгломератом духовних цінностей, які презентують особистісну позицію конкретної людини відповідно до іiі соціального статусу та ролі (студент, викладач) в освітньому просторі. В умовах реалізації навчально-виховної діяльності відбувається проекція духовних цінностей суб'єктів цієї діяльності, яка визначатиме іiї остаточну результативність - формування багатогранної цілісної особистості професіонала. 
Духовні цінності, репрезентуючись у свідомості та самосвідомості, наповнюють гуманістичним сенсом усю спонукальну сферу особистості та сприяють самореалізації іiі потенціалу (примножують таланти) (Савчин, 2011).

Зупинимось тепер конкретніше на аналізі кожного ціннісного спектру академічної доброчесності.

Чесність як особистісна цінність формується за умов актуалізації духовної інтенції «добра» та співвіднесення в свідомості людини із загальнолюдськими цінностями чесності, правдивості, принциповості, вірності прийнятим зобов'язанням, щирістю щодо інших і себе. Саме в такому широкому форматі, на думку I. Кона, і презентується чесність (Кон, 1983).

Категорія добра - абсолютна вселюдська цінність, причетність до якої наповнює життя людини сенсом; найвище благо, ціль цілей, головна мета людського життя. Деякі істотні грані категорії добра виявляють шляхом іiї протиставлення категорії зла, з'ясування їх істотних відмінностей і необхідного взаємозв'язку (Тофтул, 2014). 3 цієї визначальної особливості моральності виокремлюються два істотні моменти: перший - визнання наявності у свідомості особистості поняття про добро і зло, причому уявлення про добро як засадничу підставу моральної свідомості людині притаманне лише за умови субстанційності зла; другий - вибір особистості: вольовий акт надання переваги добру чи злу. Подібно до того, як моральне добро має своєю передумовою онтологічну й світоглядну категорію блага, яка відбиває позитивний зміст буття взагалі, пов'язаний із розвитком його різнобічних потенцій, звільненням його продуктивних засад (Малахов, 2008), піднесенням життєдайних творчих сил людини (Москалець, 1994), зло постає як усе те, що в своєму функціональному значенні підриває продуктивні потенції буття, руйнує, зокрема, умови й засоби виживання, фізичного і духовного розвитку людини, іiі життєдайних творчих потенцій (Климишин, 2013).

Цінність чесності зіставляється 3 цінністю совісності. Важливим $є$ саме аспект моральної саморегуляції, коли чесність постає як моральна цінність, моральна якість, що безпосередньо виявляється в чесній поведінці і не допускає будь-яких відхилень, незалежно від зовнішніх обставин. Як приклад, студент при написанні роботи орієнтується не на показник оцінки його роботи, зокрема, системою антиплагіат, а на власне переконання, власну оцінку себе та своєї роботи крізь призму цінності чесності.

Саме це задекларовано учасниками Бухареської конференції з етичних цінностей та принципів вищої освіти в Свропейському регіоні (2004): виховання чесності слід починати 3 себе, а вже потім добиватися ії поширення серед всіх членів академічної спільноти, не допускаючи ніяких форм обману, брехні, шахрайства, крадіжки або інших форм нечесної поведінки, які негативно впливають на якість отриманих академічних ступенів (Фініков, 2016).

Довіра як цінність у своїй суті відбиває онтологічну здатність людини вірити та вказує на моральність того, кому вірять. Беручи до уваги дослідження довіри як соціальнопсихологічного феномена, розкритого в працях І. Антоненко, Ф. Василюка, В. Зінченко, А. Купрейченко, В. Сафонова, Т. Скрипкіної ін., в аналізі довіри як ціннісного спектру академічної доброчесності ми дотримуємося думки, що довіра в умовах освітнього процесу визначатиме фон оцінки і ставлення студента як до себе і результатів власної діяльності, так і до інших та їх діяльності, які належать до конкретної академічної спільноти. Критерієм оцінки є власне система особистісних якостей і властивостей, які презентують духовну природу людини і безпосередньо проєктуються на площину освітнього процесу. 
Вочевидь рівень розвитку духовності учасників освітнього процесу визначатиме спрямованість і зміст мотивації освітньої діяльності (зовнішня чи внутрішня) та справжній смисл поведінки (орієнтований на задоволення вищих чи нижчих потреб). В умовах освітньої діяльності студент, викладач постає як активний співтворець власної особистості як професіонала в конкретній галузі знань і як особистості загалом.

Довіра, яку взаємно поділяють всі члени академічної спільноти, є основою для клімату співпраці, що сприяє вільному обміну ідеями, творчості та індивідуальному розвитку (Фішман, 1999).

Цінність справедливості в суті академічної доброчесності відбиває належний порядок функціонування академічної спільноти, належний стан взаємодії іiі членів, який встановлюється в спосіб відповідального виконання кожним 3 них своїх обов'язків i відповідну належну оцінку останніх.

Вочевидь, в умовах функціонування академічної спільноти йдеться про юридичну (правову) регламентацією «співжиття» іiі членів. В такому ракурсі справедливість постає як певна регулююча на законодавчому рівні сила, що, з одного боку, чітко означує обов'язки i права членів академічної спільноти відповідно до їх статусу, а з іншого - стоїть на їх захисті. До норм справедливості можна віднести рівність та неупередженість (Дж. Адамса). В освітньому процесі рівність стосується можливостей реалізації кожним членом академічної спільноти особистісної здатності до самодетермінації та творчої активності, самоактуалізації власних унікальних здібностей, а неупередженість - пї об'єктивної оцінки. В контексті духовної парадигми пріоритетне значення має саме вертикальна площина життєздійснення особистості. Відповідно, регламентація та оцінка особистістю власної реалізації орієнтована, передусім, не на «букву закону», а на відповідність цієї реалізації ії покликанню.

Чесне, відповідне та неупереджене оцінювання відіграє важливу роль в освітньому процесі, а справедливість тут є обов'язковою для встановлення довіри між викладачами та студентами (Фішман, 1999).

У площині духовної парадигми особистості повага постає як цінність, що опирається на автентичну духовну природу людини, іiі особистісну аксіологічність. Суть останньої полягає в двох аспектах: сакраментальності людської особистості та іiі неповторності. Особистість Іншого (студента, викладача, науковця) $є$ відмінною за цінностями, уподобаннями, життєвими переконаннями. Ця відмінність і становитиме цінність іншої людини, адже вона є такою, яка «бачить інакше», «розуміє інакше», «думає інакше».

На думку С.Франка (у його вченні про неосяжне), будь-яке безосудне самобуття стає «Я», лише виходячи за свої межі, існуючи для «Іншого» в «Іншому». Однак тут присутній і зворотний зв'язок між «Я» - «Ти», адже кожне «Ти» так само стає собою, лише «покидаючи себе задля іншого». Інший для нас подібний, як вважає М. Бахтін, до предмету: завершений в часі і просторі «естетичний», тоді як ми для себе $є$ непредметними та незавершеними. «Зовнішній» погляд на самих себе формують «Інші», внутрішній світ яких ми пізнаємо шляхом діалогу. Лише в стосунку до «Іншого» пізнається власне «Я» як самість та знаходиться власна відмінність (Климишин, 2013).

Повага передбачає сприймання іншої людини, передусім, як суб’єкта, а не об'єкта взаємодії. Неможливо оволодіти внутрішньою людиною, побачити і зрозуміти, роблячи ii об'єктом нейтрального аналізу (Срмоленко, 1999). 
Водночас повага характеризується відчуттям духовної свободи меж власної активності, можливостей пізнання «Іншого», розкриття себе, свободи оцінки себе, обставин свого життя та самовизначення.

Вільний обмін ідеями і свобода висловлювань базуються на взаємній повазі, яку поділяють всі члени академічної спільноти, незалежно від їх положення в освітній і науковій ієрархії. Без такого обміну рівень академічної й наукової творчості знижується (Фішман, 1999).

Biдnовідальність як ціннісний спектр академічної доброчесності безпосередньо стосується духовної свободи кожного члена академічної спільноти. Усі члени академічної спільноти мають певні обов'язки. І власне якою мірою вони виконують чи не виконують свої обов'язки - це і є питання про їх моральну відповідальність. Їх безпосередній моральний обов'язок - бути чесним, справедливим, виявляти повагу і довіру. Освітня діяльність передбачає прояви свободи та відповідальності водночас.

Свобода вибору, як безпосередній прояв духа, робить людину спроможною обирати спосіб свого життєздійснення - стати активним творцем себе і навколишньої дійсності, помножуючи добро, любов, істину або ж стати пасивним спостерігачем, споживачем, живучи «за рахунок інших» і дбаючи виключно про свій комфорт.

Створюючи нові смислові конструкти в умовах освітньої діяльності, яка повинна мати передусім творчий характер, як студент, так і викладач, науковець виступає творцем, що $є$ вільний у ставленні до навколишньої дійсності, до інших. Свобода виводить людину за межі дії необхідних сил. Автономність і спонтанність «Я» є проявом його зв'язку 3 «ншим». Вільне «Я» наче заглиблюється у всеєдність «Ми» (яким виступає суспільство), знаходячи в ній грунт для своєї свободи (Климишин, 2013). Свобода лише заради свободи призводить до відсутності обов'язків і зобов'язань, що породжує відчуття порожнечі (Савчин, 2019).

Ситуація прояву свободи вибору вимагає від особистості прийняття відповідальності за його здійснення. Як ось, підготовка творчих завдань студентом ставить його в ситуацію вибору - реалізувати власну креативність, доклавши вольових зусиль у пізнанні, чи піти іншим шляхом, скориставшись «плодами зусиль інших».

Відповідальність за дотримання принципів доброчесності є як особистим обов’язком, так і спільною справою. Кожен член академічної спільноти - студент, член професорськовикладацького складу, представник адміністрації, несуть відповідальність за дотримання принципів академічної доброчесності під час навчання, викладання і здійснення наукових досліджень (Фішман, 1999).

Саме мужність як цінність забезпечує можливість функціональної дієвості розглянутих вище цінностей, їх перехід у формат конкретних вчинків - вчинку чесності, справедливості, поваги, довіри. Мужність як цінність зіставляється 3 такими рисами характеру особистості, як сміливість, рішучість, твердість характеру, безкомпромісність.

Мужність бути академічно доброчесним передбачає готовність відстоювати ії як у спосіб особистого прикладу, так і в спосіб активного протистояння порушенням, не боячись наслідків стати «соціально непривабливим», адже не кожна академічна спільнота у своїй суті може бути зорієнтованою на справді дотримання академічної доброчесності, а не лише на їі проголошення.

Власне, саме в цьому аспекті ми повертаємось до висхідної думки, з якої починали розгляд питання академічної доброчесності, - гідності людини. Здатність відрефлексовувати власні вчинки, здійснювати моральну оцінку своїх дій, керуючись іманентною здатністю до 
вибору добра і заперечення зла та орієнтація на відповідний ціннісний стандарт визначають «санкціонуючу дієвість» гідності.

Показником мужності, як ціннісного спектру академічної доброчесності, є здатність протистояти моральному релятивізму, який знаходить очевидні прояви і в освітньому просторі та є ознакою антропологічної кризи сучасного суспільства. Не може бути подвійних стандартів в оцінці чесності або поваги, справедливості чи довіри.

Члени академічних спільнот мають навчитися не лише приймати стійкі та непохитні рішення, але й демонструвати відвагу, яка є необхідною для того, щоб зафіксувати їх не лише словом, але і ділом. Лише через постійне плекання відваги можливе створення та підтримка сильних спільнот доброчесності, які залишатимуться відповідальними, надійними, шанобливими, чесними, справедливими, незважаючи на обставини, з якими вони можуть зіткнутися (Фішман, 1999).

Формування академічної доброчесності відбувається в умовах деонтологічного вибору. Духовні цінності, які становлять суть академічної доброчесності, актуалізуються в свідомості студента, викладача (відповідно до конкретної ситуації вибору в умовах освітнього процесу), проходять щоразу «внутрішнє переосмислення» крізь призму деонтичного вибору та прийняття відповідальності за його здійснення, за наслідки, після чого відбувається реалізація цих цінностей в дієвий вчинковий спосіб.

У своєму виборі духовної спрямованості, зокрема, академічної доброчесності, особистість постає вільним суб'єктом власної позиції. Ця свобода визначається функціонуванням внутрішнього, а не зовнішнього, цензора - совісті, яка виступає автономною духовною інстанцією, що виходить із власних підстав, глибоких пластів несвідомого (Франкл, 1997).

Водночас можна стверджувати про певний показник сформованості академічної доброчесності. Його визначатимуть наявність знань, розуміння суті категорій чесності, довіри, справедливості, поваги, відповідальності та мужності, суб'єктивне прийняття або ж неприйняття останніх i, власне, реалізація відповідного ставлення у вчинковий спосіб. Показник сформованості академічної доброчесності можна зіставити з рівнем духовного розвитку особистості.

Академічна доброчесність на інтрасуб'єктному рівні функціонування особистості передбачає активність самокерування, що базується на осмисленому прийнятті цінностей чесності, довіри, справедливості, поваги, відповідальності й мужності як мотивів самовдосконалення. Реалізація академічної доброчесності в процесі міжособистісної взаємодії на інтерсуб'єктному рівні передбачає прояв чесності, довіри, справедливості, поваги, відповідальності та мужності у ставленні до Іншого. На метасуб'єктному рівні академічна доброчесність презентується, передусім, в двох ракурсах - здатності суб'єкта освітнього процесу пізнавати та творити. Суб'єкт передусім засвоює знання, в яких зафіксований соціальний досвід суспільства, що підлягає суспільно-історичним законам та внутрішній логіці свого розвитку і сам створює нові значення, які мають об'єктивовану суспільну значимість та входять в загальну модель об' єктивного відображення навколишньої дійсності. На цьому рівні відбувається залучення суб'єкта до духовної культури суспільства, його надбань як активного споживача, носія і творця останньої. 


\section{Висновки}

Проаналізовані нами ціннісні спектри академічної доброчесності в контексті духовної парадигми психології засвідчують важливість формування останньої в умовах сучасних академічних спільнот та освітніх установ. Коли суспільні освітні установи «просякнуті» доброчесністю, вони допомагають у створенні міцнішої громадянської культури суспільства як цілого.

Формування академічної доброчесності в академічних спільнотах $\epsilon$ певним «вчинковим співавторством», де вчинкові дії кожного іiі представника, не втрачаючи мотиваційної вартості у площині власного особистісного розвитку, виходять в площину спільного діяння на благо спільноти, людства загалом. Ідейна суголосність представників академічної спільноти щодо академічної доброчесності, їх щоденний особистий внесок в іiі пропагування, найперше, через особистий приклад здатні реально змінити якість освітнього процесу. В свою чергу, від того, яким уже сьогодні буде освітній і культурний простір нашого суспільства, залежатиме формування майбутніх поколінь.

Наголошено на необхідності реалізації нової освітньої парадигми, метою якої $\epsilon$, передусім, виховання нової особистості, орієнтованої на систему духовних цінностей. Це питання значно масштабніше у своїй функціональній суті, адже залишає за кожною людиною, як представником соціальної спільноти (не лише академічної спільноти) можливість бути і самоздійснюватись у іiї вищому трансцендентному вимірі.

Перспективи подальших розвідок вбачаємо в емпіричному дослідженні кореляції академічної доброчесності та рівня розвитку духовності особистості, а також означенні механізмів оптимізації процесу формування академічної доброчесності в закладах освіти.

\section{Література}

1. Антоненко, И.В. (2004). Доверие: социально-психологический феномен. (Монографія). Москва : Социум.

2. Бахтин, М.М. (1979). Эстетика словесного творчества. Москва : Искусство.

3. Василюк, Ф.Е. (1984). Психология переживания (анализ преодоления критических ситуаций). Москва : Изд-во Моск. Ун-та.

4. Выготский, Л.С. (2000). Психология. Москва : Изд-во ЭКСМО-Пресс.

5. Зинченко, В.П. (2002). Размышления о душе и ее воспитании. Вопросы философии, 2, 119-136.

6. Єрмоленко, А.М. (1999). Комунікативна практична філософія. Київ : Лібра.

7. Киричук, О.В., Киричук, В.О., \& Киричук, В.В. (2008). Народження та зростання духовної особистості: теорія, діагностика, тренінг. Київ : ВМГО «Союз обдарованої молоді».

8. Климишин, О.I. (2013). Християнсько-психологічні основи духовного розвитку особистості (Дис. д-ра. психол. наук). Київ.

9. Кон, И.С. (1983). Словарь по этике. Москва : Политиздат.

10. Купрейченко, А.Б. (2008). Психология доверия и недоверия. Москва : Изд-во «Институт психологии РАН».

11. Малахов, В.А. (2008). Право бути собою. Київ : ДУХ і ЛІТЕРА.

12. Москалець, В.П. (1994). Психологічне обтрунтування украӥнської національної школи. Львів : Світ. 
13. Налимов, В.В. \& Дрогалина, Ж.А. (1984). Вероятностная модель бессознательного. Бессознательное как проявление семантической вселенной. Психологический журнал, 5(6), 111-121.

14. Савчин, М. (2019). Здоров'я людини: духовний, особистісний i тілесний виміри. (Монографія). Дрогобич : ПП ПОСВІТ.

15. Савчин, М. (2011). Дослідження особистості в контексті духовної парадигми психології. Психологія особистості, 1, 191-199.

16. Скрипкина, Т.П. (2000). Психология доверия. Москва : Издательский центр «Академия».

17. Сафонов, В.С. (1978). Особенности доверительного общения (Автореф. дис. канд. психол. наук). Москва.

18. Тофтул, М.Г. (2014). Сучасний словник з етики. Житомир : Вид-во ЖДУ ім. І. Франка.

19. Фініков, Т. (2016). Академічна доброчесність: глобальний контекст та національна потреба. Т.В. Фінікова \& А.Є. Артюхова (Ред.), Академічна чесність як основа сталого розвитку університету. (с. 9-37). Київ: Таксон. Режим доступу: https://drive.google.com/file/d/0ByePGdGpHh6Wa1NoR3g4S1FaWVE/view

20. Фішман, Т. (Ред.). (1999). Фундаментальні цінності академічної доброчесності. Клемсон : Університет Клемсон. Режим доступу: http://www.academicintegrity.org/icai/

21. Франк, С.Л. (1992). Духовные основы общества. Москва : Республика.

22. Франкл, В. (1997). Доктор и душа. Санкт-Петербург : «Ювента».

\section{References}

1. Antonenko, I.V. (2004). Doveriye: sotsial'no-psikhologicheskiy fenomen. [Trust: a sociopsychological phenomenon]. Moscow : Sotsium [in Russian].

2. Bakhtin, M.M. (1979). Estetika slovesnogo tvorchestva [Aesthetics of verbal creativity]. Moscow : Iskusstvo [in Russian].

3. Vasyliuk, F.E. (1984). Psykholohyia perezhyvanyia (analyz preodolenyia krytycheskykh sytuatsyi) [Psychology of experience (analysis of overcoming of critical situations)]. Moscow : Izd-vo Mosk. Un-ta [in Russian].

4. Vygotskiy, L.S. (2000). Psikhologiya [Psychology]. Moscow : Izd-vo EKSMO-Press [in Russian].

5. Zynchenko, V.P. (2002). Razmyshlenyia o dushe y ee vospytanyy [Reflections on the soul and its upbringing]. Voprosy fylosofyy - Questions of philosophy, 2, 119-136 [in Russian].

6. Yermolenko, A.M. (1999). Komunikatyvna praktychna filosofiia. [Communicative practical philosophy]. Kyiv : Libra [in Ukrainian].

7. Kyrychuk, O.V., Kyrychuk, V.O., \& Kyrychuk, V.V. (2008). Narodzhennia ta zrostannia dukhovnoi osobystosti: teoriia, diahnostyka, treninh. [Birth and growth of spiritual personality: theory, diagnosis, training]. Kyiv : VMHO "Soiuz obdarovanoi molodi" [in Ukrainian].

8. Klymyshyn, O.I. (2013). Khrystyiansko-psykholohichni osnovy dukhovnoho rozvytku osobystosti [Christian-psychological foundations of spiritual development of personality]. Extended abstract of Candidate's thesis. Kyiv [in Ukrainian].

9. Kon, Y.S. (1983). Slovar' po etike [Dictionary of ethics]. Moscow : Polytyzdat [in Russian].

10. Kupreychenko, A.B. (2008). Psikhologiya doveriya i nedoveriya [The psychology of trust and distrust]. Moscow : Izd-vo "Institut psikhologii RAN" [in Russian].

11. Malakhov, V.A. (2008). Pravo buty soboyu [The right to be yourself]. Kyiv : DUKH i LITERA [in Ukrainian]. 
12. Moskalets', V.P. (1994). Psykholohichne obgruntuvannya ukrayins'koyi natsional'noyi shkoly [Psychological substantiation of the Ukrainian national school]. Lviv : Svit [in Ukrainian].

13. Nalimov, V.V., \& Drogalina, ZH.A. (1984). Veroyatnostnaya model' bessoznatel'nogo. Bessoznatel'noye, kak proyavleniye semanticheskoy vselennoy [The probabilistic model of the unconsciousness. The unconsciousness as a manifestation of the semantic universe]. Psikhologicheskiy zhurnal - Psychological journal, 5(6), 111-121 [in Russian].

14. Savchyn, M. (2019). Zdorovia liudyny: dukhovnyi, osobystisnyi i tilesnyi vymiry. [Human health: spiritual, personal and physical dimensions]. Drohobych : PP POSVIT [in Ukrainian].

15. Savchyn, M. (2011). Doslidzhennia osobystosti v konteksti dukhovnoi paradyhmy psykholohii [The study of personality in the context of the spiritual paradigm of psychology]. Psykholohiia osobystosti - Personality psychology, 1, 191-199 [in Ukrainian].

16. Skripkina, T.P. (2000). Psikhologiya doveriya [The psychology of trust]. Moscow : Izdatel'skiy tsentr «Akademiya» [in Russian].

17. Safonov, V.S. (1978). Osobennosti doveritel'nogo obshcheniya [Features of confidential communication]. Extended abstract of Candidate's thesis. Moscow [in Russian].

18. Toftul, M.H. (2014). Suchasnyy slovnyk z etyky [Modern dictionary of ethics]. Zhytomyr : Vydvo ZHDU im. I. Franka [in Ukrainian].

19. Finikov, T. (2016). Akademichna dobrochesnist: hlobalnyi kontekst ta natsionalna potreba [Academic integrity: global context and national need]. In T.V. Finikov \& A.Ye. Artyukhov (Eds.), Akademichna chesnist yak osnova staloho rozvytku universytetu - Academic honesty as a basis for sustainable development of the university (p. 9-37). Kyiv : Takson. Retrieved from https://drive.google.com/file/d/0ByePGdGpHh6Wa1NoR3g4S1FaWVE/view [in Ukrainian].

20. Fishman, T. (1999). Fundamentalni tsinnosti akademichnoi dobrochesnosti [The Fundamental Values of Academic Integrity]. Klemson : Universytet Klemson. Retrieved from http://www.academicintegrity.org/icai/ [in Ukrainian].

21. Frank, S.L. (1992). Dukhovnyye osnovy obshchestva [Spiritual foundations of society]. Moscow : Respublika [in Russian].

22. Frankl, V. (1997). Doktor i dusha [Doctor and soul]. Sankt-Peterburg: "Yuventa" [in Russian]. 


\title{
HERMENEUTICS OF ACADEMIC INTEGRITY IN THE CONTEXT OF THE SPIRITUAL PARADIGM OF PSYCHOLOGY Olha Klymyshyn \\ Doctor of Sciences in Psychology, Associate Professor, Professor of the Department of Developmental Psychology \\ Vasyl Stefanyk Precarpathian National University \\ 57, Shevchenko Str., Ivano-Frankivsk, Ukraine, 76005 \\ klymyshyn@meta.ua, https://orcid.org/0000-0002-3943-4397
}

\begin{abstract}
In the context of educational reforms with a focus on European standards, there is a need to understand the fundamental values on which the educational process should be based and implemented. The article presents the results of the study of academic integrity as a conglomeration of spiritual values that demonstrate the personal position of the representative of the academic community in the educational space. The purpose of the studies to reveal the content of the phenomenon of academic integrity in the context of the spiritual paradigm of psychology. Objectives of the study are to determine the methodological provisions of the spiritual paradigm of psychology and reveal the content of the value spectra of academic integrity in the context of the spiritual paradigm of psychology. Such theoretical methods as analysis, synthesis, comparison. generalization and systematization of theoretical approaches and views to the problem of academic integrity, psychological hermeneutics were used. The starting point of the analysis of academic integrity in the context of the spiritual paradigm of psychology is the consideration of the personality of the academic community as a noological entity characterized by potential universality, creative and volitional orientation, immanent ability to choose good and deny evil, ontological attitude to self-knowledge. Spiritual values, which are the essence of academic integrity, are actualized in the minds of students, teachers (according to the specific situation of choice in the educational process). Each time these values are processed by "internal rethinking" through the prism of deontic choice and responsibility for its implementation realization of these values in a deed.
\end{abstract}

Keywords: personality, academic integrity, spirituality, spiritual values, honesty, trust, justice, respect, responsibility, courage.

Подано 09.12.2020

Рекомендовано до друку 22.12.2020 